\title{
INTEGRASI PENDIDIKAN KARAKTER KE DALAM PEMBELAJARAN KEWARGANEGARAAN DI SEKOLAH DASAR
}

\author{
Machful Indra Kurniawan \\ e-mail: Machful.indra.k@gmail.com
}

\begin{abstract}
This study aims to integrate character education into teaching civics in elementary school, specifically aims to (1) identify the values corresponding character integrated into Civics subjects SD (2) character value integrate into the elementary civics lesson. The design of research studies are exploratif with data sources in the form of documents such as books and expert opinions about character education, civic education content standards in 2006 about SK and KD Civics SD. The instrument used to collect the data that is documentation. Based on the analysis results of the study showed that (1) values corresponding characters integrated into the elementary civics subjects, namely: social Caring, intelligent, patriotic, democratic, disciplined, honest, hard work, reward achievement, caring environment, curiosity, national spirit, responsibility, and tolerance, (2) integration of the device into the character value of elementary civics lesson is done by understanding the substance of SK and KD. Cognitively, the concept of what is in SK and KD. Understand the concept and expected behavior in SK and $\mathrm{KD}$ to be key in the development of indicators. Of these indicators will become a reference in developing evaluation tools and teaching materials. Of teaching materials will guide in choosing learning methods.
\end{abstract}

\begin{abstract}
Abstrak: Penelitian ini bertujuan untuk mengintegrasikan pendidikan karakter ke dalam pembelajaran PKn di SD, secara khusus bertujuan untuk (1) mengidentifikasi nilai-nilai karakter yang sesuai diintegrasikan kedalam mata pelajaran PKn SD (2) mengintegrasikan nilai karakter ke dalam pembelajaran PKn SD. Rancangan penelitian tergolong penelitian exploratif dengan sumber data berupa dokumen yang berupa buku dan pendapat para ahli tentang pendidikan karakter, Standar isi PKn tahun 2006 tentang SK dan KD PKn SD. Instrumen yang digunakan untuk mengumpulkan data yaitu dokumentasi. Berdasarkan hasil analisis didapatkan hasil penelitian yaitu (1) Nilai-nilai karakter yang sesuai diintegrasikan ke dalam mata pelajaran PKn SD, yaitu: Peduli sosial, cerdas, cinta tanah air, demokratis, disiplin, jujur, kerja keras, menghargai prestasi, peduli lingkungan, rasa ingin tahu, semangat kebangsaan, tanggung jawab, dan toleransi; (2) Pengintegrasian nilai karakter kedalam perangkat pembelajaran PKn SD dilakukan dengan cara memahami substansi SK dan KD.
\end{abstract}

Kata Kunci: pendidikan karakter, pendidikan kewarganegaraan di sekolah dasar

Sesuatu yang amat ironis ketika kita sering mendengar dari televisi, radio, dan surat kabar tentang perilaku penyimpangan moral yang dilakukan oleh para siswa, seperti kebut-kebutan di jalan, penggunaan narkoba, dan seks bebas yang mengakibatkan hamil di luar nikah. Tidak hanya itu saja, setelah selesai ujian nasional, mereka berhamburan keluar ke jalan raya, berpawai, corat-coret tembok, bahkan ada yang terli- bat perkelahian. Hal tersebut menunjukkan bahwa tidak ada bekas dari apa yang dipelajari siswa di sekolah untuk diwujudkan dalam kehidupan keseharian mereka. Boleh jadi apa yang diujikan tersebut tidak ada hubunganya dengan apa yang ada dalam kehidupan sehari-hari.

Dihidupkannya kembali pendidikan budi pekerti secara tidak langsung memberi anggapan bahwa pendidikan kewarga- 
negaraan yang berfungsi sebagai pendidikan moral yang telah berlangsung selama ini dinilai gagal dalam menciptakan manusia yang bermoral dan berakhlak sesuai dengan misi dan tujuannya. Merebaknya praktek-praktek kolusi, korupsi dan budaya nepotisme pada masa pemerintahan Orde Baru hingga pemerintahan saat ini semakin menegaskan tuduhan gagalnya pembelajaran pendidikan kewarganegaraan.

Pendidikan budi pekerti mempunyai esensi dan makna yang sama dengan pendidikan karakter, yaitu membentuk pribadi anak, supaya menjadi manusia yang baik, warga masyarakat, dan warga negara yang baik, sehingga mampu mengantisipasi gejala krisis moral dan berperan dalam rangka pembinaan generasi muda.

Pentingnya membangun pendidikan karakter nampaknya mendapatkan perhatian dari pemerintah, salah satunya dapat dilihat dari pidato menteri pendidikan nasional ketika memperingati HARDIKNAS pada tahun 2010 dengan tema "Pendidikan Karakter untuk Membangun Peradaban Bangsa”. Dalam pidatonya menteri pendidikan menyatakan bahwa pendidikan karakter menjadi suatu keharusan, karena pendidikan tidak hanya menjadikan peserta didik menjadi cerdas, melainkan juga harus mempunyai budi pekerti dan sopan santun, sehingga keberadaannya sebagai anggota masyarakat menjadi bermakna baik bagi dirinya maupun masyarakat pada umumnya" (Sumber: www.kemdiknas.go.id)

Selanjutnya Menteri Pendidikan Nasional dalam pertemuan dengan pimpinan Pascasarjana Lembaga Pendidikan Tenaga Kependidikan (LPTK) se-Indonesia di Auditorium Universitas Negeri Medan megatakan "Pendidikan karakter harus dmulai dari SD karena jika karakter tidak terbentuk sejak dini maka akan susah untuk merubah karakter seseorang" (sumber: www.webcache.googleusercontent.com)

Pentingnya pendidikan karakter yang dicanangkan oleh Pemerintah melalui
Menteri Pendidikan Nasional, sejak awal sudah disadari oleh para Pendiri Negara founding fathers. Sejak proklamasi kemerdekaan, para founding fathers telah meyadari bahwa untuk dapat mewujudkan citacita Indonesia maka yang dibangun bukan hanya negara (staate), tetapi juga bangsa (nation). Bahkan pembangunan bangsa menjadi lebih penting dan menjadi perhatian utama, karena kemajuan negara sangat ditentukan oleh kualitas bangsa. Oleh karena itu, para founding fathers menekankan pentingnya pembangunan karakter (Warsono, 2010).

Berdasarkan pernyataan tersebut membuktikan bahwa penerapan pendidikan karakter kedalam pembelajaran nampaknya menjadi suatu keharusan, karena dinilai mampu menjadikan peserta didik menjadi cerdas, melainkan juga mampu menjadikan peserta didik mempunyai budi pekerti dan sopan santun sehingga keberadaannya sebagai anggota masyarakat menjadi bermakna baik bagi dirinya maupun masyarakat pada umumnya.

Pendidikan Kewarganegaraan merupakan salah satu program pendidikan yang memiliki ruang lingkup yang cukup luas dan meliputi sedikitnya tiga domain dalam proses pembangunan karakter, yakni (1) secara konseptual pendidikan kewarganegaraan berperan dalam mengembangkan konsep-konsep dan teori, (2) secara kurikuler Pendidikan kewarganegaraan mengembangkan sejumlah program pendidikan dan model implementasinya dalam mempersiapkan peserta didik menjadi manusia dewasa yang berkarakter melalui lembagalembaga pendidikan, dan (3) secara sosial kultural pendidikan kewarganegaraan melaksanakan proses pembelajaran kepada masyarakat agar menjadi warga negara yang baik. Sebagai bagian dari kurikulum pendidikan nasional yang tertera dalam UU No. 20 tahun 2003 tentang Sisdiknas, program pendidikan kewarganegaraan berlandaskan pada Pancasila dan UUD 1945, ber- 
fungsi mengembangkan kemampuan dan membentuk watak serta peradaban bangsa yang bermartabat dalam rangka mencerdaskan kehidupan bangsa, bertujuan untuk berkembangnya potensi peserta didik agar menjadi manusia yang beriman dan bertakwa kepada Tuhan Yang Maha Esa, berakhlak mulia, sehat, berilmu, cakap, kreatif, mandiri, dan menjadi warganegara yang demokratis serta bertanggung jawab. Hal tersebut menunjukan bahwa pendidikan kewarganegaraan mempunyai peran yang penting dan strategis dalam pelaksanakan pendidikan karakter.

Implementasi pendidikan karakter ke dalam proses pembelajaran tidak dapat dilaksanakan apabila guru belum bisa mengintegrasikan kedalam perangkat pembelajaran. Dalam Pengintegrasian nilai-nilai karakter kedalam perangkat pembelajaran tidak dapat di integrasikan secara begitu saja, melainkan harus menyesuaikan terlebih dahulu nilai-nilai karakter dengan standar kompetensi dan kompetensi dasar. Dalam membuat perangkat pembelajaran dalam hal ini RPP guru harus memperhatikan nilai-nilai karakter yang sesuai dengan tujuan pembelajaran yang tertuang dalam Standar Kompetensi dan Kompetensi dasar.

Pemerintah melalui kementrian pendidikan nasional dan deparrtemen agama sering mengadakan kegiatan berupa seminar atau pelatihan tentang pendidikan karakter yang pesertanya adalah para pendidik mulai dari SD, SMP, dan SMA. Dengan diadakannya seminar atau pelatihan tentang pendidikan budaya karakter, diharapkan guru mampu menerapkan dan mengintegrasikan pendidikan karakter dalam proses pembelajaran di sekolah. Namun, pelatihan atau seminar yang pernah diikuti oleh guru tampaknya belum berhasil secara optimal. Sering dijumpai guru-guru yang masih kebingungan dalam pengimplementasian pendidikan karakter ke dalam proses pembelajaran, terutama dalam menginte- grasikan nilai-nilai karakter ke dalam perangkat pembelajaran. Dalam pengintegrasian nilai-nilai karakter kedalam perangkat pembelajaran, seringkali tidak relevan dengan standar kompetensi dan kompetensi dasar dan terkesan dipaksakan.

Dari uraian diatas, dapat dirumuskan permasalahan yaitu:

1. Nilai-nilai karakter apa saja yang sesuai diintegrasikan ke dalam mata pelajaran pendidikan kewarganegaraan di sekolah dasar?

2. Bagaimana pengintegrasian nilai-nilai karakter ke dalam pembelajaran pendidikan kewarganegaraan di sekolah dasar?

\section{KAJIAN TEORI}

\section{A. Kajian Umum Tentang Pendidikan Karakter}

\section{Pengertian pendidikan karakter}

Undang-Undang No. 20 tahun 2003 tentang Sistem Pendidikan Nasional. Pasal 3 UU Sisdiknas menyebutkan "Pendidikan nasional berfungsi mengembangkan kemampuan dan membentuk watak serta peradaban bangsa yang bermartabat dalam rangka mencerdaskan kehidupan bangsa, bertujuan untuk mengembangkan potensi peserta didik agar menjadi manusia yang beriman dan bertakwa kepada Tuhan Yang Maha Esa, berakhlak mulia, sehat, berilmu, cakap, kreatif, mandiri, dan menjadi warga negara yang demokratis serta bertanggungjawab". Tujuan pendidikan nasional tersebut merupakan rumusan mengenai kualitas manusia Indonesia yang harus dikembangkan oleh setiap satuan pendidikan. Oleh karena itu rumusan tujuan pendidikan nasional menjadi dasar dalam pengembangan pendidikan karakter.

Karakter adalah watak, tabiat, akhlak, atau juga kepribadian seseorang yang terbentuk dari hasil internalisasi berbagai kebajikan yang diyakini dan mendasari ca- 
ra pandang, berpikir, sikap, dan cara bertindak orang tersebut. Kebajikan tersebut terdiri atas sejumlah nilai, moral, dan norma seperti jujur, berani bertindak, dapat dipercaya, hormat kepada orang lain (Kemendiknas 2010).

Beberapa ahli menyatakan bahwa nilai karakter memiliki keteraitan dengan nilai moral. Jack corly dan Thomas Philip (2000) sebagaimana yang dikutip oleh Warsono (2010) mengemukakan bahwa karakter merupakan sikap dan kebiasaan seseorang yang memungkinkan dan mempermudahkan tindakan seseorang. Lebih lanjut dijelaskan bahwa karakter adalah kualitas seseorang jika seseorang mempunyai moral yang baik maka akan memiliki karakter yang baik yang terwujud dalam siikap dan prilaku dalam kehidupan seharihari, oleh sebab itu pendidikan karakter menjadi penting dan strategis membangun bangsa.

Pendidikan karakter adalah proses pemberian tuntunan peserta didik agar menjadi manusia seutuhnya yang berkarakter dalam dimensi hati, pikir, raga, serta rasa dan karsa. dengan kata lain, karakter dimaknai sebagai kualitas pribadi yang baik, dalam arti tahu kebaikan, mau berbuat baik, dan nyata berpilaku baik, yang secara koheren memancar sebagai dari olah pikir, olah hati, olah raga, dan olah rasa dan karrsa (Warsono 2010).

Sedangkan menurut Sudrajat (2010) pendidikan karakter adalah suatu sistem penanaman nilai-nilai karakter kepada warga Negara sekolah yang meliputi komponen pengetahuan, kesadaran atau kemauan, dan tindakan untuk melaksanakan nilainilai tersebut, baik terhadap tuhan YME, diri sendiri, sesama, lingkungan, maupun kebangsaan sehingga menjadi manusia insan kamil.

Berdasarkan beberapa pengertian diatas dapat disimpulkan bahwa pendidikan karakter adalah suatu proses penanaman nilai-nilai karakter kepada peserta didik agar menjadi manusia seutuhnya yang berkarakter dalam dimensi hati, pikir, raga, serta rasa dan karsa. dengan kata lain, karakter dimaknai sebagai kualitas pribadi yang baik, dalam arti tahu kebaikan, mau berbuat baik, dan nyata berperilaku baik.

2. Fungsi Pendidikan Karakter

Menurut kemendiknas (2010: 7) fungsi pendidikan karakter antara lain:

a. Wahana pengembangan, yakni: pengembangan potensi peserta didik untuk menjadi berperilaku yang baik bagi peserta didik yang telah memiliki sikap dan perilaku yang mencerminkan karakter.

b. Wahana perbaikan, yakni: memperkuat kiprah pendidikan nasional untuk lebih bertanggungjawab dalam pengembangan potensi peserta didik yang lebih bermartabat.

c. Wahana penyaring, yakni: untuk menyaring budaya-budaya bangsa sendiri dan budaya bangsa lain yang tidak sesuai dengan nilai-nilai karakter.

3. Tujuan Pendidikan Karakter

Menurut kemendiknas (2010: 7) tujuan pendidikan karakter antara lain:

a. Mengembangkan potensi kalbu/nurani atau afektif peserta didik sebagai manusia dan warganegara yang memiliki nilai-nilai karakter.

b. Mengembangkan kebiasaan dan perilaku peserta didik yang terpuji dan sejalan dengan nilai-nilai universal dan tradisi budaya bangsa yang religius.

c. Menanamkan jiwa kepemimpinan dan tanggung jawab peserta didik sebagai generasi penerus bangsa.

d. Mengembangkan kemampuan peserta didik menjadi manusia yang mandiri, kreatif, berwawasan kebangsaan.

e. Mengembangkan lingkungan kehidupan sekolah sebagai lingkungan belajar yang aman, jujur, penuh kreativitas dan persahabatan, serta dengan rasa kebangsaan yang tinggi dan penuh kekuatan (dignity). 


\section{Nilai-nilai dalam Pendidikan Karakter}

Nilai-nilai yang dikembangkan dalam pendidikan karakter diidentifikasi dari berbagai sumber sebagai berikut:

\section{a. Agama}

Masyarakat Indonesia adalah masyarakat beragama. Oleh karena itu kehidukehidupan kehidupan individu, masyarakat dan bangsa selalu didasari pada ajaran agama dan kepercayaannya. Secara politis kehidupan kenegaraan pun didasari oleh nilai-nilai yang berasal dari agama. Atas dasar pertimbangan itu, maka nilai-nilai pendidikan karakter harus didasarkan pada nilai-nilai dan kaidah yang berasal dari agama.

\section{b. Pancasila}

Negara Kesatuan Republik Indonesia ditegakkan atas prinsip-prinsip kehidupan kebangsaan dan kenegaraan yang disebut Pancasila. Pancasila terdapat pada Pembukaan UUD 1945 dan dijabarkan lebih lanjut dalam pasal-pasal yang terdapat dalam UUD 1945 tersebut. Artinya, nilai-nilai yang terkandung dalam Pancasila menjadi nilai-nilai yang mengatur kehidupan politik, hukum, ekonomi, kemasyarakatan, budaya, dan seni yang diatur dalam pasal-pasal UUD 1945. Pendidikan karakter bertujuan mempersiapkan peserta didik menjadi warga negara yang lebih baik, yaitu warga negara yang memiliki kemampuan, kemauan, dan menerapkan nilai-nilai Pancasila dalam kehidupannya sebagai warga negara. c. Budaya

Adalah suatu kebenaran bahwa tidak ada manusia yang hidup bermasyarakat yang tidak didasari oleh nilai-nilai budaya yang diakui masyarakat tersebut. Nilainilai budaya tersebut dijadikan dasar dalam memberi makna terhadap suatu konsep dan arti dalam komunikasi antar anggota masyarakat tersebut. Posisi budaya yang demikian penting dalam kehidupan masyarakat mengharuskan budaya menjadi sumber nilai-nilai dari pendidikan karakter.

\section{d. Tujuan Pendidikan Nasional}

Tujuan pendidikan nasional mencerminkan kualitas yang harus dimiliki setiap warga negara Indonesia, dikembangkan oleh berbagai satuan pendidikan di berbagai jenjang dan jalur. Dalam tujuan pendidikan nasional terdapat berbagai nilai kemanusiaan yang harus dimiliki seorang warga nega ra Indonesia. Oleh karena itu, tujuan pendidikan nasional adalah sumber yang paling operasional dalam pengembangan pendidikan karakter dibandingkan ketiga sumber yang disebutkan di atas (Kemendiknas 2010: 7). Berdasarkan keempat sumber nilai tersebut maka teridentifikasi sejumlah nilai untuk pendidikan karakter.

\section{B. Pendidikan Kewarganegaraan di Sekolah Dasar}

Pendidikan kewarganegaraan di sekolah dasar dituangkan dalam lampiran Permendiknas No. 22 tahun 2006, dalam lampiran tersebut dikemukakan bahwa "mata pelajaran pendidikan kewargenegaraan merupakan mata pelajaran yang memfokuskan pada membentukkan warga negara yang memahami dan mampu melaksanakan hak-hak dan kewajibannya untuk menjadi warga negara Indonesia yang cerdas, terampil, dan berkarakter yang diamanatkan oleh Pancasila dan UUD 1945" sedangkan tujuannya digariskan dengan tegas adalah agar peserta didik memiliki kemampuan sebagai berikut:

1. Berpikir secara kritis, rasional, dan kreatif dalam menanggapi isu kewarganegaraan.

2. Berpartisipasi secara aktif dan bertanggung jawab, dan bertindak secara cerdas dalam kegiatan bermasyarakat, berbangsa, dan bernegara serta anti korupsi.

3. Berkembang secara positif dan demokratis tis untuk membentuk diri berdasarkan karakter-karakter masyarakat Indonesia agar dapat hidup bersama dengan bangsa-bangsa lain. 
4. Berinteraksi dengan bangsa-bangsa lain dalam peraturan dunia secara langsung atau tidak langsung dengan memanfaatkan teknologi informasi dan komunikasi.

\section{Integrasi Nilai-nilai Pendidikan Karakter Dalam Pembelajaran}

Menurut kemendiknas (2010: 18), nilai-nilai pendidikan karakater diintegrasikan dalam setiap pokok bahasan dari setiap mata pelajaran. Nilai-nilai tersebut dicantumkan dalam silabus dan RPP dengan melalui cara-cara berikut ini:

a. Mengkaji Standar Komptensi (SK) dan Kompetensi Dasar (KD) pada Standar Isi (SI) untuk menentukan apakah nilainilai budaya dan karakter bangsa yang tercantum itu sudah tercakup di dalamnya.

b. Memilih karakter yang memperlihatkan keterkaitan antara SK dan KD dengan nilai dan indikator untuk menentukan nilai yang akan dikembangkan.

c. Mencantumkan nilai-nilai karakter tersebut ke dalam silabus.

d. Mencantumkan nilai-nilai yang sudah tertera dalam silabus ke dalam RPP.

Berdasarkan hal tersebut dapat disim pulkan bahwa RPP mempunyai peranan penting dalam pengintegrasian nilai-nilai pendidikan karakter ke dalam proses pembelajaran di sekolah. RPP merupakan gambaran tentang pembelajaran yang akan dilakukan dalam proses pembelajaran.

Lebih lanjut Warsono (2010) menjelaskan, adapun langkah-langkah yang harus dilakukan dalam menyususun RPP, sebagai berikut:

1. Memahami substansi SK dan KD, baik dari ranah kognitif, afektif, maupun psikomotor (jika ada).

2. Menyusun indikator yang didasarkan pada hasil pemahaman SK dan KD.

3. Menyusun alat evaluasi.

4. Menyusun materi ajar.
5. Memilih metode pembelajaran

Berdasarkan langkah-langkah di atas dapat dijelaskan bahwa dalam menyusun RPP hal yang perlu dilakukan adalah memahami substansi SK dan KD. Secara kognitif, konsep apa yang ada didalam SK dan KD. Pemahaman konsep dan perilaku yang diharapkan didalam SK dan KD menjadi kunci dalam penyusunan indikator. Dari indikator tersebut akan menjadi acuan dalam menyusun alat evaluasi dan materi ajar. Dari materi ajar akan memandu dalam memilih metode pembelajaran.

\section{METODE}

Penelitian ini merupakan penelitian ekploratif, yaitu salah satu penelitian sosial yang tujuannya untuk memberikan sedikit definisi atau penjelasan mengenai konsep atau pola yang digunakan dalam penelitian. (Neuman: 2003). Tujuan dari penelitian ini adalah untuk menjadikan topik baru lebih dikenal oleh masyarakat luas, memberikan gambaran dasar mengenai topik bahasan, menggeneralisasi gagasan dan mengembangkan teori yang bersifat tentatif.

Data yang dibutuhkan dalam penelitian ini adalah dokumen tentang buku pendidikan karakter dan Standar isi PKn tahun 2006 tentang SK dan KD pendidikan kewarganegaraan di sekolah dasar. Data yang terkumpul kemudian dianalisis dengan cara mengkaji Standar Kompetensi (SK) dan Kompetensi Dasar (KD) pada Standar Isi (SI), kemudian Memilih nilai karakter yang memperlihatkan keterkaitan antara SK dan KD dengan nilai dan indikator. Dengan demikian kita dapat mengetahui nilai-nilai karakter yang sesuai dengan pendidikan kewarganegaraan sekolah dasar.

\section{HASIL DAN PEMBAHASAN}

Nilai-nilai Karakter yang Sesuai diintegrasikan ke Dalam Mata pelajaran 


\section{Pendidikan Kewarganegaraan di Sekolah Dasar}

Nilai karakter merupakan hal yang paling penting dalam proses pembelajaran pendidikan karakter di sekolah dasar terutama mata pelajaran PKn. Pemilihan nilai karakter ke dalam pembelajaran PKn SD tidak bisa diintegrasikan secara begitu saja, memelainkan harus disesuaikan dengan tujuan pembelajaran PKn. Data nilai-nilai karakter yang sesuai dengan pembelajaran PKn di SD diperoleh dengan cara mengkaji Standar Kompetensi (SK) dan Kompetensi Dasar (KD) pada Standar Isi (SI), kemudian memilih nilai karakter yang memperlihatkan keterkaitan antara SK dan KD dengan nilai dan indikator.

Berdasarkan analisis antara SK, KD dan indikator, maka nilai karakter yang sesuai dengan tujuan pembelajaran PKn SD.

\section{PEMBAHASAN DAN HASIL PENELITIAN}

Hasil yang tercapai dalam penelitian ini adalah tersedianya prototipe berupa pedoman integrasi pendidikan karakter ke dalam pembelajaran PKn SD. Prototipe integrasi pendidikan karakter ke dalam pembelajaran dapat dijadikan pedoman guru dalam penerapan pendidikan karakter ke dadalam proses pembelajaran PKn di SD. Da- lam bab ini akan didiskusikan hal-hal yang berkaitan dengan hasil penelitian baik yang berhubungan dengan pemilihan nilai karakter dan pengintegrasian nilai karakter ke dalam perangkat pembelajaran.

\section{Integrasi Nilai-nilai pendidikan karakter kedalam pembelajaran PKn SD}

Penelitian ini menghasilkan prototipe berupa pedoman integrasi pendidikan karakter ke dalam pembelajaran PKn sekolah dasar. Diskusi hasil penyusunan prototipe tentang integrasi pendidikan karakter ke da lam pembelajaran PKn di sekolah dasar diuraikan sebagai berikut.

\section{Nilai-nilai karakter PKn sekolah dasar}

Nilai karakter yang sesuai dengan pembelajaran PKn SD dalam penelitian ini berjumlah 13 nilai karakter. Data nilai karakter yang sesuai dengan pendidikan kewarganegaraan di sekolah dasar diperoleh dengan menggunakan analisis data, dengan cara mengkaji Standar Komptensi (SK) dan Kompetensi Dasar (KD) pada Standar Isi (SI) PKn sekolah dasar untuk menentukan apakah nilai-nilai karakter yang tercantum itu sudah tercakup di dalamnya, kemudian memilih nilai karakter yang memperlihatkan keterkaitan antara SK dan KD PKn sekolah dasar dengan nilai karakter dan indi-kator. Dalam menentukan nilai karakter, penentu harus menyesuaikan antara $\mathrm{SK} / \mathrm{KD}$ dan indikator dengan nilai karakter yang terkandung dalam tujuan pembelajaran.

Adapun hasil analisis tentang nilai karakter yang sesuai dengan pendidikan kewarganegaraan di sekolah dasar dapat dilihat dalam tabel pada lembar lampiran.

2. Integrasi pendidikan karakter ke dalam pembelajaran PKn di SD

Pengintegrasian nilai-nilai pendidikan karakter ke dalam pembelajaran PKn SD dapat dilakukan dengan cara mencantumkan nilai-nilai karakter kedalam silabus dan RPP. Dalam mencantumkan nilai-nilai karakter kedalam Silabus dan RPP langkah yang dilakukan, yaitu :

1) Memahami substansi $S K$ dan $K D$, baik dari ranah kognitif, afektif, maupun psikomotor (jika ada).

2) Menyusun indikator yang didasarkan pa- da hasil pemahaman SK dan KD.

3) Menentukan nilai karakter yang memperlihatkan keterkaitan antara SK dan KD dengan nilai karakter dan indikator.

4) Menyusun alat evaluasi.

5) Menyusun materi ajar. 
6) Memilih metode pembelajaran.

Dalam mencantumkan nilai-nilai karakter kedalam Silabus dan RPP hal yang perlu dilakukan yaitu, memahami substansi SK dan KD. Secara Kognitif, konsep apa yang ada di dalam SK dan KD. Kemudian memahami konsep dan perilaku yang diharapkan di dalam SK dan KD menjadi kunci dalam penyusunan indikator. Dari indikator tersebut akan menjadi acuan dalam menyusun alat evaluasi dan materi ajar. Dari materi ajar akan memandu dalam memilih metode pembelajaran.

\section{PENUTUP}

Dengan memperhatikan proses integrasi nilai-nilai pendidikan karakter dan ha- sil penelitian, dapat disimpulkan halhal se- bagai berikut.

1. Nilai-nilai karakter yang sesuai diintegrasikan ke dalam mata pelajaran PKn di SD, yaitu: Peduli sosial, cerdas, cinta tanah air, demokratis, disiplin, jujur, kerja keras, menghargai prestasi, peduli lingkungan, rasa ingin tahu, semangat kebangsaan, tanggungjawab, dan toleransi.

2. Pengintegrasian nilai-nilai pendidikan karakter ke dalam pembelajaran $\mathrm{PKn}$ SD dapat dilakukan dengan cara mencantumkan nilai-nilai karakter ke dalam silabus dan RPP. Dalam mencantumkan nilai-nilai karakter kedalam Silabus dan RPP hal yang perlu dilakukan yaitu, memahami substansi SK dan KD. Secara Kognitif, konsep apa yang ada di dalam SK dan KD. Memahami konsep dan perilaku yang diharapkan di dalam SK dan KD menjadi kunci dalam penyusunan indikator. Dari indikator tersebut akan menjadi acuan dalam menyusun alat evaluasi dan materi ajar. Dari materi ajar akan memandu dalam memilih metode pembelajaran.

\section{DAFTAR PUSTAKA}

Depdiknas. 2008. Pengembangan Silabus Dan Rencana Pelaksanaan Pembelajaran Dalam KTSP. Jakarta: Direktur Tenaga Pendidikan, Dirjen P- MPTK, Depdiknas.

Depdiknas. 2008a. Panduan Pengmbangan Bahan Ajar. Jakarta: Direktorat Pembinaan SMA, Dirjen Mandikdasmen, Depdiknas.

Depdiknas. 2008b. Peraturan Menteri Pendidikan Nasional RI Nomor 2 tahun 2008 Tentang Buku. Jakarta: Depdiknas.

Depdiknas 2003. Undang-undang Nomor 20 Tahun 2003 tentang Sistem PenPendidikan Nasional, Jakarta: Depdiknas.

Hasan Said Hamid, dkk. 2010. Bahan Pelatihan Penguatan Metodologi Pembelajaran Berdasarkan NilaiNilai Budaya Untuk Membentuk Daya Saing Dan Karakter Bangsa: Jakarta: Kemendiknas.

Hudoyo, H. 1988. Mengajar Belajar Matematika. Jakarta: Dirjen Dikti Depdiknas.

Ismail, R, Hasan. Pengertian Respon. 2009 ,(www.hasanismailr.blogspot.com, diakses 10 April 2011).

Neuman, CW. Cawrence. 2003. Social Research Methods: United States of America.

Permendiknas No. 22 tahun 2006 tentang Standar Isi: Lampiran Standar Isi Pendidikan Kewarganegaraan (PKn).

Rusdi, Sandi. Perangkat Pembelajaran, (www://webcache.googlecontent.co

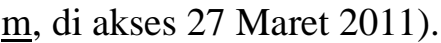

Sudjana, 2001. Metode Statistika. Bandung: Gramedia Pustaka Utama

Suparno, P. 2001. Teori Perkembangan Kognitif Jean Piaget. Yogyakarta: Kanisus. 
Trianto, 2007. Model Pembelajaran Terpadu dalam Teori dan Praktek. Surabaya: Prestasi Pustaka.

Undang-undang No. 20 Tahun 2003 TenTentang Sistem Pendidikan Nasional.

Warsono, 2010. Pendidikan Dalam Bidang Studi IPS Karakter Melalui, Semi- nar Nasional Pendidikan Karakter, Kerjasama Himpunan Sarjana Pendidikan Ilmu-Ilmu Sosial Indonesia (HISPISI) \& UNESA, Surabaya, 18-19 Juni 2011. 